\title{
PENGATURAN LUAS TANAM SEBAGAI INSTRUMEN KEBIJAKAN STABILISASI HARGA DAN PENDAPATAN PETANI: STUDI KASUS KOMODITI CABE DI PULAU LOMBOK, INDONESIA
}

\author{
DETERMINATION OF PLANTING SIZE AS AN POLICY \\ INSTRUMENT OF PRICE AND INCOME STABILIZATION: A CASE \\ STUDY OF SMALL CHILLI IN LOMBOK, INDONESIA
}

Anas Zaini, M. Siddik, I Ketut Budastra, M. Zubair dan Suparmin

Program Studi Agribisnis Fakultas Pertanian Universitas Mataram

\begin{abstract}
ABSTRAK
Berbeda dengan strategi stabilisasi untuk komoditi biji-bijian yang dapat disimpan lama, kebijakan stabilisasi untuk cabe rawit dilakukan melalui pengaturan waktu dan luas tanam karena komoditi ini umumnya dikonsumsi dalam kondisi segar. Dengan menggunakan data harga di tingkat konsumen bulanan (2012-2016) dan dianalisis menggunakan model program linear untuk memaksimumkan penerimaan maka luas optimal penanaman cabe di musim kemarau adalah 1.418 hektar per bulan sementara di musim hujan adalah 1.786 hektar per bulan dengan nilai penerimaan 846.299.124.300 rupiah. Selain itu hasil penelitian mengindikasikan harga cabe pada musim kemarau sekitar Rp. 64.638 per kg di musim kemarau sementara di musim hujan Rp. 36.644 per kilogram. Menstabilkan harga pada nilai rata-ratanya dapat meningkatkan kemakmuran masyarakat.
\end{abstract}

Kata kunci: stabilisasi, kebijakan, harga, cabe

\begin{abstract}
Unlike stabilization strategy for food grains that can be done through buffer stock, --as it can be stored for long time before it is consumed--, stabilization policy for small chilli have to be undertaken through managing planting size as the commodity is mostly consumed in fresh condition after harvest. Using montly price data at consumers level and analyzed using linear programming model to maximize revenue, we found that the optimum planting size of small chilli in dry season is around 1.418 hectare each month while in rainy season is about 1.786, generating revenue 846.299.124.300 rupiah. Result also indicated that small chilli price would be around Rp. 64.638 per kilogram in dry season while it would be about Rp. 36.644 per kilogram in rainy season. Stabilizing the price around its mean value could benefited society as a whole.
\end{abstract}

Key words: stabilization, policy, price, chilli, 


\section{PENDAHULUAN}

Selama lebih dari 40 tahun sejak NTB mengalami krisis pangan di awal tahun 1970an, para pihak di daerah maupun pusat memprioritaskan daerah ini sebagai salah satu sentra produksi pangan khususnya padi/beras. Hal ini telah mengakibatkan petani dan pemerintah daerah terperangkap dan tidak berani keluar dari ketergantungan terhadap beras sementara kondisi lingkungan internal dan eksternal telah jauh berubah. Dengan penguasaan lahan sawah untuk pertanaman padi per kapita saat ini sudah sangat berkurang, yaitu sekitar 0,33 hektar/petani, sementara untuk Pulau Lombok angkanya lebih kecil lagi yaitu hanya 0,26 hektar/petani, tentunya sangat tidak mungkin keluarga petani akan sejahtera bila menggantungkan hidupnya pada usahatani padi yang harga produknya dikendalikan pemerintah karena beras merupakan bahan makanan pokok (staple food). Dengan demikian jika ingin mensejahterakan petani maka pemerintah daerah secara bertahap harus berani meninggalkan ketergantungan terhadap padi/beras dan memfasilitasi pengembangan komoditi pertanian lain yang potensi keuntungannya tinggi karena harganya tidak dikendalikan pemerintah. Hal ini sekaligus merupakan upaya untuk memperbaiki nilai tukar petani (NTP) yang cenderung stagnan di daerah ini (Zaini, 2014; Zaini, et al., 2014).

Salah satu komoditi pertanian yang potensial memperbaiki NTP karena dapat memberikan imbal hasil tinggi adalah komoditi cabe kecil. Namun demikian agribisnis ini merupakan salah satu komoditi pertanian yang paling sering mengalami fluktuasi harga musiman. Oleh karena itu ia semestinya dikembangkan melalui pendekatan yang komprehensif mengingat fluktuasi harga tersebut sangat tajam pada saat harga "anjlok" dengan harga ketika "melambung", seperti terlihat pada gambar 1. Dari gambar tersebut terlihat bahwa harga riil cabe di Pulau Lombok sangat fluktuatif dengan harga terrendah Rp. 415 per kilogram terjadi pada bulan Desember 2003 sedangkan harga tertinggi terjadi pada bulan Maret 2011 dengan harga Rp.90.750 per kilogram. Agribisnis cabe dengan demikian tergolong usaha yang penuh risiko namun memiliki potensi penerimaan tinggi, high risk but high return.

Karena sifatnya yang sering berfluktuasi secara tajam tersebut maka cabe merupakan komoditi penyumbang penting laju inflasi daerah dan nasional sehingga Bank Indonesia senantiasa mengawasi pergerakan harga cabe di setiap daerah. Dengan karakteristik harga yang sering berfluktuasi tersebut maka peran penelitian perguruan tinggi menjadi sangat penting dan semakin tertantang guna menemukan solusi untuk menstabilkan harga dan pendapatan petani cabe di daerah ini (BI, 2012).

Masalahnya adalah upaya stabilisasi harga dan pendapatan petani cabe, seperti umumnya produk hortikultura lainnya, tidak dapat dilakukan seperti halnya pada produk biji-bijian (food grain) yang dapat disimpan lama. Terhadap produk biji-bijian stabilisasi harga dan pendapatan petani dilakukan melalui pembelian oleh pemerintah (baca BULOG) pada saat panen raya dan menyimpannya sebagai cadangan di gudang pemerintah (buffer stock) untuk kemudian dijual ke pasar ketika terjadi kekurangan produksi pada saat panen. 


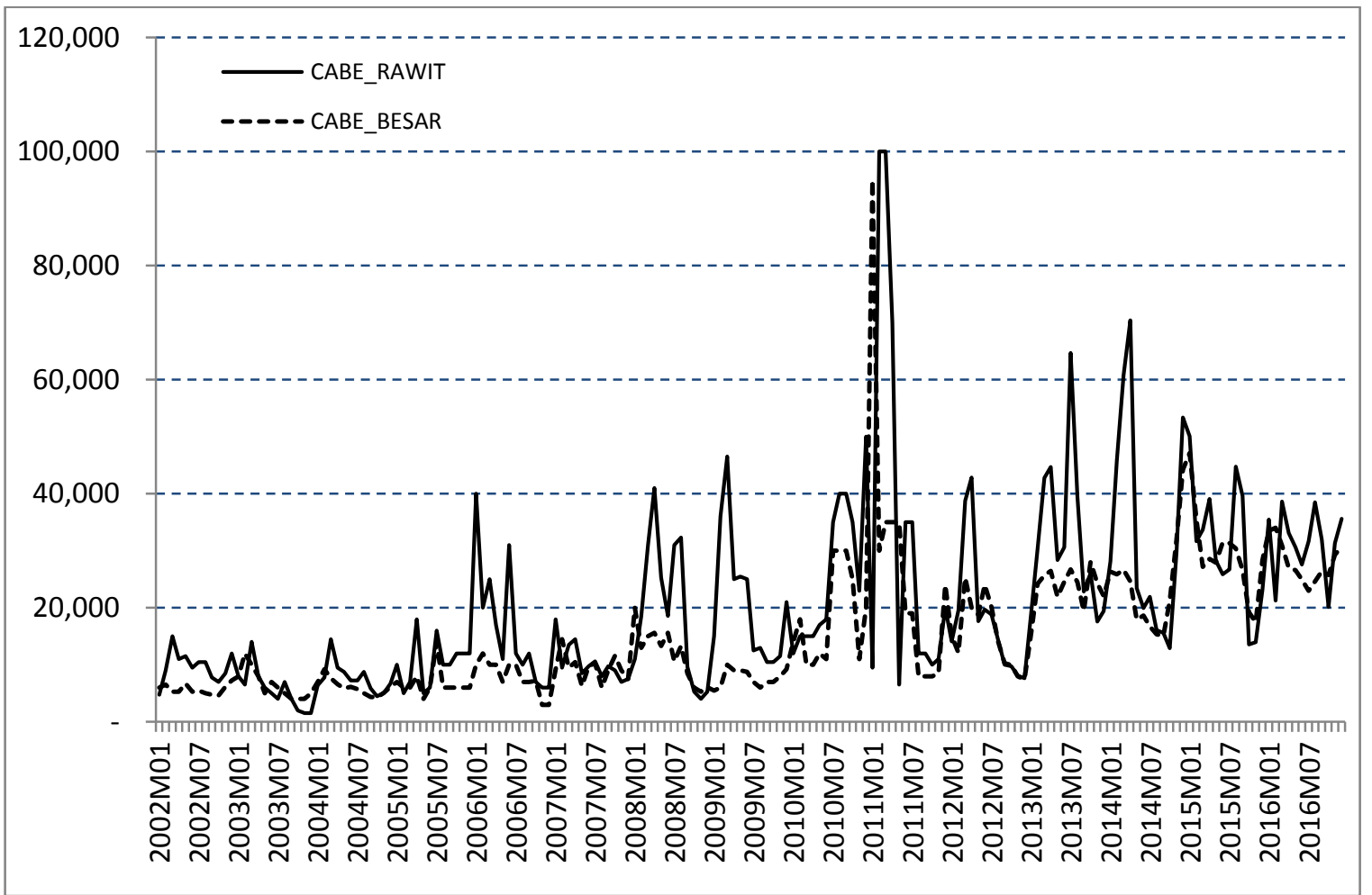

Gambar 1. Perkembangan harga cabe di Nusa Tenggara Barat tahun 2002-2016

Untuk produk sayuran seperti cabe yang mudah rusak, upaya stabilisasi dilakukan melalui pengaturan tata tanam yang tepat karena komoditi ini tidak dapat disimpan lama dalam kondisi segar. Pada saat banyak petani melakukan penanaman cabe dan iklim mendukung, produksi melimpah sementara pemerintah tidak melakukan pembelian sehingga terjadi over suplai yang menekan harga di pasar domestik.. Namun ketika hasil panen menurun, harga cabe domestik pun naik namun petani tidak dapat memanfaatkan kenaikan harga ini karena terdapat gestation period yang cukup lama saat bibit ditanam sampai tanaman mulai berproduksi. Berdasarkan kompleksitas persoalan tersebut maka penelitian mengenai Pengaturan Tata Tanam sebagai Instrumen Kebijakan Stabilisasi Harga dan Pendapatan Petani Cabe di Pulau Lombok penting dilakukan.

Penelitian ini memiliki tujuan utama menemukan pola tata tanam cabe yang kondusif bagi terciptanya stabilitas harga dan pendapatan petani cabe di Pulau Lombok. Pengaturan tata tanam menyangkut luas dan waktu penanaman dengan mengacu pada harga referensi cabe berdasarkan hasil penelitian terdahulu. Selain itu penelitian ini juga memiliki target khusus menghasilkan satu skripsi mahasiswa S1 serta satu artikel untuk dipublikasikan di prosiding seminari nasional. Selain itu hasil penelitian ini merupakan sumber bahan ajar untuk mata kuliah Pembangunan dan Kebijakan Pertanian serta mata kuliah Riset Operasi. 
Penelitian mengenai stabilisasi harga komoditi pertanian dan pendapatan petani di Indonesia umumnya dilakukan terhadap komoditi pangan pokok berupa biji-bijian seperti padi/beras, jagung atau kedele yang dapat disimpan lama (Islam and Thomas, 1996). Sepanjang menyangkut produk hortikultura terutama sayuran (cabe) yang mudah rusak, stabilisasi harga umumnya dilakukan dengan membuka keran impor ketika terjadi goncangan pada sisi produksi (supply shock), sementara petani tidak memiliki akses terhadap pasar ekspor jika terjadi over suplai. Oleh karena itu penelitian mengenai stabilisasi harga dan pendapatan petani cabe melalui pengaturan tata tanam dapat memberikan kontribusi praktis bagi petani dan pemerintah serta kontribusi teoritis yang melengkapi alternatif kebijakan stabilisasi yang sudah ada.

\section{METODE PENELITIAN}

Penelitian dilakukan dengan menggunakan data sekunder yang berasal dari Dinas Pertanian, Dinas Perindustrian dan Perdagangan Propinsi Nusa Tenggara Barat (Dinas Perindag NTB) dan Badan Pusat Statistik (BPS NTB). Data sekunder harga cabe berasal dari Dinas Perindag berupa data rentang waktu (time series) bulanan sedangkan data produksi bulanan diperoleh dari Dinas Pertanian dan BPS NTB dari tahun 2012-2016.

Tata tanam usahatani cabe didefinisikan sebagai kegiatan mengatur awal musim penanaman cabe dan luas tanamnya dengan tujuan untuk stabilisasi harga dalam kerangka memaksimumkan pendapatan. Analisis data dilakukan dengan menggunakan linear programming dengan model produksi multi periode (multiperiod production model) yang dirumuskan sebagai berikut:

\section{Variabel Keputusan (Decision Variables)}

Varibel keputusan dari model produksi multi periode ini adalah besarnya luas tanam cabe yang harus dilakukan untuk setiap periode musim (bulanan) selama satu tahun, dirumuskan sebagai $L T_{n}$ dimana $L T$ adalah luas tanam dan $n$ adalah periode tanam, diukur dalam hektar (ha). Selain variabel keputusan, dirumuskan pula variabel antara sebagai berikut:

a. $L P_{i}$ adalah Luas Panen yang besaran luasnya merupakan diukur dalam hektar (ha).

b. $P_{i}$ adalah harga cabe pada periode panen $i$, diukur dalam rupiah (Rp).

c. $Y_{i}$ adalah produktivitas cabe pada periode panen $i$, diukur dalam kuital per hektar (ku/ha).

\section{Fungsi Tujuan (Objective Function)}

Tujuan model pengaturan pola tata tanam usahatani cabe adalah memaksimumkan penerimaan petani cabe selama periode waktu tertentu (1 tahun). Penerimaan diperoleh dengan mengalikan luas tanam dan produktivitas dengan harga pada masing-masing periode. Fungsi tujuan dengan demikian dirumuskan sebagai $\operatorname{Max} \sum_{i=1}^{12} Y_{i} L T_{i} P_{i}$ 


\section{Fungsi Pembatas}

Tanaman cabe mulai berbuah pada umur 11 minggu dan dapat dipanen secara bertahap dalam jumlah semakin meningkat hingga pada umur tertentu, kemudian menurun hingga tanaman mati. Untuk menjaga stabilitas supply, waktu penanaman lakukan bertahap, maka panen juga dilakukan secara bertahap sehingga jumlah panen pada periode $i$ merupakan hasil panen pada tanaman yang ditanam pada periode $i-11, i$ $12, \ldots, i-m$. Pohon cabe yang ditanam tidak selamanya dapat dipanen karena ada kematian atau terserang penyakit yang menyebabkan pohon cabe tidak dapat berbuah. Jika $\propto$ adalah koefisien kegagalan panen, maka luas panen dapat dirumuskan sebagai berikut: $L P_{i}=\propto * L T$

Namun dalam penelitian ini petani diasumsikan melakukan penyulaman segera untuk menjamin luas panen sama dengan luas tanam.

Perumusan fungsi pembatas dilakukan pada masing-masing periode musim guna mendapatkan harga keseimbangan pada setiap musim. Model linear lengkap untuk mengetahui pola tata tanam cabe dengan demikian menjadi:

$$
\begin{aligned}
& \operatorname{Max} \sum_{i=1}^{12} Y_{i} L T_{i} P_{i} \\
& \sum_{\mathrm{ST}}^{9} L T_{i} \leq \sum_{i=4}^{9} L P_{i} \\
& \sum_{i=4}^{3} L T_{i} \leq \sum_{i=10}^{3} L P_{i} \\
& L T_{i} \leq L P_{i} \\
& L T_{i}, L P_{i}, Y_{i}, P_{i} \geq 0
\end{aligned}
$$

dimana,

Yi = Rata-rata produktivitas cabe rawit bulan $\mathrm{ke} \mathrm{i}(\mathrm{Ku} / \mathrm{Ha})$

$\mathrm{LPi}=$ Rata-rata luas panen bulan ke $\mathrm{i}(\mathrm{Ha})$

$\mathrm{Pi}=$ Rata-rata harga cabe rawit bulan ke $\mathrm{i}(\mathrm{Rp} / \mathrm{Kg})$

$\mathrm{LTi}=$ Luas tanam pada bulan ke $\mathrm{i}(\mathrm{Ha})$

$\mathrm{i}=$ bulan (1=Januari, $2=$ Februari, ............, 12=Desember),

$=4 \mathrm{~s} / \mathrm{d} 9$ periode musim kemarau (April - September)

$=10 \mathrm{~s} / \mathrm{d} 3$ periode musim hujan (Oktober - Maret). 


\section{HASIL DAN PEMBAHASAN}

\section{Hasil optimasi luas dan waktu tanam}

Setelah dilakukan analisis optimasi mengunakan Solver Excel diperoleh hasil sebagai berikut:

Tabel 1. Hasil optimasi luas dan waktu tanam

\begin{tabular}{|l|l|}
\hline Objective & $8,462,991,243$ (00 rp) \\
\hline
\end{tabular}

\begin{tabular}{|c|c|}
\hline Variabel & Value \\
\hline LT4 & 1,418 \\
\hline LT5 & 1,418 \\
\hline LT6 & 1,418 \\
\hline LT7 & 1,418 \\
\hline LT8 & 1,418 \\
\hline LT9 & 1,418 \\
\hline LT10 & 1,786 \\
\hline LT11 & 1,786 \\
\hline LT12 & 1,786 \\
\hline LT1 & 1,786 \\
\hline LT2 & 1,786 \\
\hline LT3 & 1,786 \\
\hline
\end{tabular}

Berdasarkan hasil optimasi tersebut diperoleh luas penanaman cabe rawit optimal pada musim kemarau (April-September) adalah 1.418 hektar per bulan, sedangkan pada musim hujan (Oktober-Maret) adalah 1.786 hektar dengan nilai penerimaan 846.299.124.300 rupiah atau 846,3 miliar rupiah per tahun.

Setelah diperoleh luas tanam optimum untuk masing-masing periode tanam maka langkah selanjutnya adalah melakukan kalkulasi produksi dan harga keseimbangan yang terjadi. Dengan menggunakan model dan hasil estimasi fungsi permintaan cabe rawit (Zaini dan Siddik, 2019) kemudian dilakukan simulasi dampak stabilisasi harga cabe pada masing-masing periode. Hasilnya adalah harga keseimbangan pada penanaman musim kemarau adalah Rp. 64.638/kg sedangan pada musim penghujan adalah Rp. 36.644/kg.

\section{Manfaat stabilisasi harga model Waugh-Massell}

Dari hasil penelitian terdahulu, Zaini (2014) dan Zaini et al., (2014) mengindikasikan bahwa gejolak harga cabe disebabkan adanya fluktuasi pada sisi produksi. Oleh karena itu analisis kebijakan stabilisasi harga dilakukan dengan menggunakan kerangka analisis Waugh-Massell yang mengasumsikan sumber gejolak harga adalah adanya shock pada sisi produksi (Mattew, et al., 2004; Schmitz, et al., 2002; Van Kooten and Schmitz, 1985). 


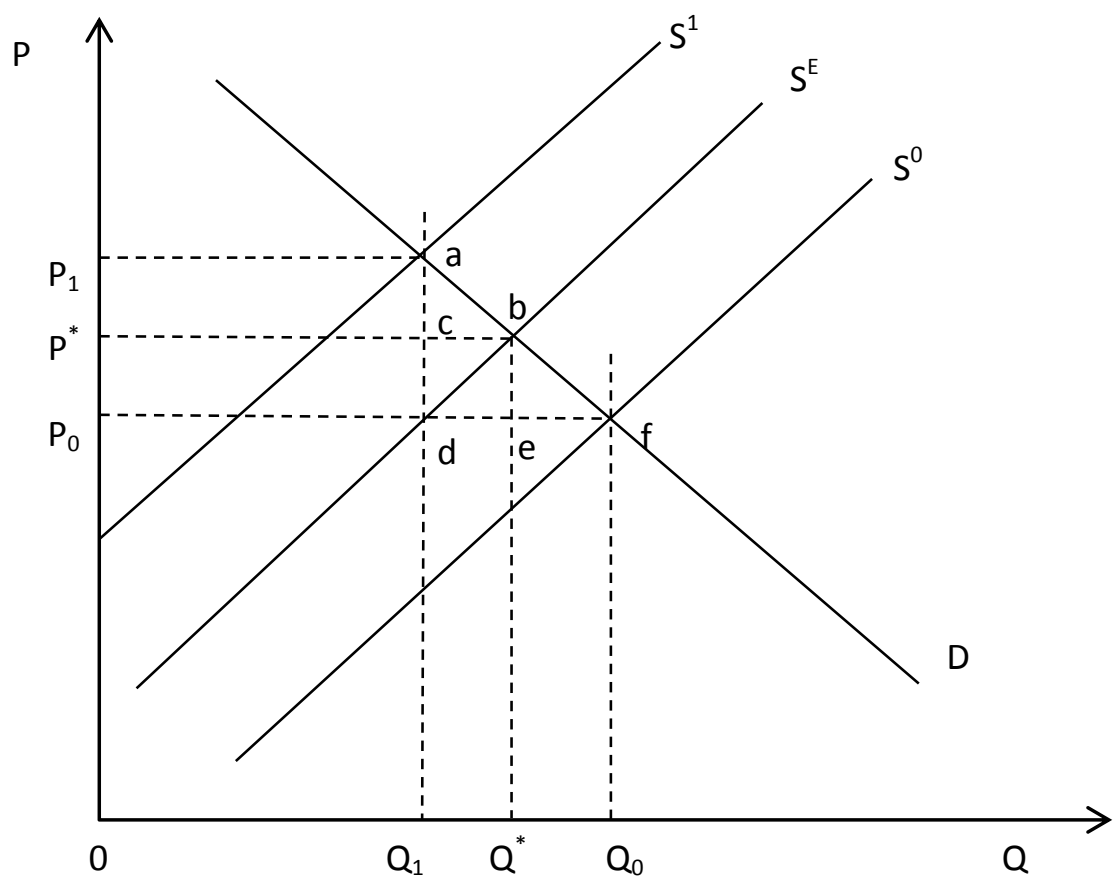

Gambar 2. Stabilisasi harga model Waugh-Massell

Perhatikan Gambar 2, pemerintah sebagai otoritas yang memiliki kewenangan melakukan stabilisasi harga mengetahi bahwa kurva penawaran cabe berfluktuasi secara random di sekitar kurva penawaran harapan $\left(\mathrm{S}_{\mathrm{E}}\right)$. Dengan menggunakan model WaughMassel, peluang terjadinya kurva penawaran $S_{0}$ dan $S_{1}$ masing-masing sebesar 0,5 dan biaya stabilisasi diasumsikan nol serta konsumen bersikap netral terhadap risiko. Namun pada kondisi dimana produsen menghadapi ketidakpastian harga akibat pergeseran kurva penawaran, maka tingkat kemakmuran yang dihadapi oleh produsen (petani) menurut Schmitz (1984) dan Van Kooten and Schmitz (1985) ditentukan oleh selisih antara penerimaan harapan (expected gross revenue) pada harga yang distabilisasi dikurangi dengan penerimaan tanpa stabilisasi. Dengan demikian manfaat harapan bersih (net expected gain) bagi produsen setelah stabilisasi harga pada dua periode musim tersebut dinyatakan sebagai berikut:

Manfaat bagi produsen $=($ Penerimaan dengan stabilisasi $)-($ Penerimaan tanpa stabilisasi $)$

$$
\begin{aligned}
& =2 P^{*} Q^{*}-\left(P_{0} Q_{0}+P_{1} Q_{1}\right) \\
& =\text { daerah }\left(P^{*} \text { be } P_{0}-Q^{*} \text { ef } Q_{0}\right)+\operatorname{daerah}\left(Q_{1} c b Q^{*}-P_{1} a c P^{*}\right) .
\end{aligned}
$$

Berdasar kaidah simetri : daerah $\left(Q_{1} d e Q^{*}=Q^{*} e f Q_{0}\right)$, dan daerah $\left(P_{1} a c P^{*}=P^{*} c d P_{0}\right)$.

Dengan demikian, manfaat bersih bagi produsen $=2 \mathrm{x}$ daerah (cbed)

Di lain sisi, manfaat stabilisasi bagi konsumen dinyatakan oleh daerh $\left(P_{1} a b P^{*}\right)$ sedangkan kerugiannya daerah $\left(P^{*} b f P_{0}\right)$. Nilai kerugian harapan bagi konsumen 
(expected consumers loss), dengan demikian, adalah daerah segi empat cbed karena berdasarkan kaidah simetri daerah $a b c=$ daerah $b f e$. Akhirnya manfaat sosial stabilisasi harga bagi masyarakat ditunjukkan oleh daerah $c b e d$.

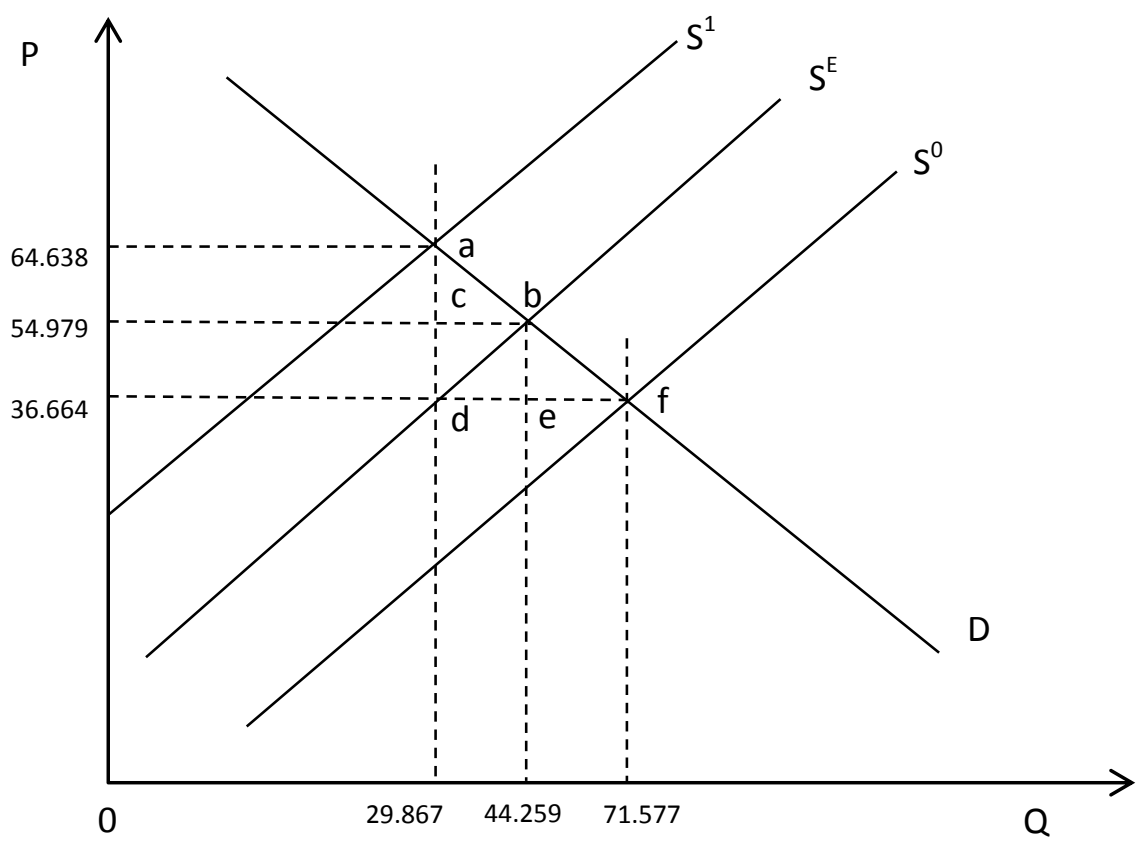

Gambar 3. Hasil stabilisasi model Waugh-Massell

Berdasarkan Gambar 3 tersebut, manfaat harapan stabilisasi bagi petani cabe adalah $2 \mathrm{x}$ $($ daerah cbed $)$ yaitu $2 \times(18.315 \times 14.392)=527.178 .960,00$. Karena produksi dinyatakan dalam satuan kuintal dan harga dalam satuan Rp/kg maka manfaat bagi produsen dengan demikian adalah 52.717.896.000,00 atau 52,7 milyar rupiah per tahun (dua musim). Bagi kosumen, kerugian harapan dari stabilisasi harga adalah daerah cbed, yaitu (18.315 x $14.392) \times 100=26.358 .948 .000,00$ atau 26,4 milyar per tahun. Dengan demikian, secara keseluruhan manfaat sosial harapan dari stabilisasi harga cabe adalah 52.717.896.000,00 26.358.948.000,00 $=26.358 .948 .000,00$ atau 26,4 milyar rupiah per tahun. 


\section{KESIMPULAN DAN REKOMENDASI}

\section{Kesimpulan}

1) Hasil optimasi menunjukkan bahwa luas penanaman cabe rawit optimal pada musim kemarau (April-September) adalah 1.418 hektar per bulan, sedangkan pada musim hujan (Oktober-Maret) adalah 1.786 hektar dengan nilai penerimaan 800,4 miliar rupiah per tahun.

2) Simulasi berdasarkan dugaan fungsi permintaan dan penawaran cabe rawit pada kondisi optimum menghasilkan harga keseimbangan penanaman musim kemarau adalah Rp. 64.638/kg sedangan pada musim penghujan adalah Rp. 36.644/kg.

3) Stabilisasi harga pada nilai tengah memberikan manfaat sosial semilai 26,4 milyar rupiah per tahun.

\section{Rekomendasi}

Berdasarkan temuan tersebut maka pembuat kebijakan sebaiknya melakukan pengaturan tata tanam cabe dalam rangka stabilisasi harga dan pendapatan petani. Pengaturan luas dan waktu tanam optimal tersebut memerlukan koordinasi antar dinas pertanian kabupaten untuk mempertahankan luas panen sesuai perencanaan saat penanaman.

\section{DAFTAR PUSTAKA}

[BI] Bank Indonesia, 2012. Laporan Penelitian Pengembangan Komoditas/Produk/Jasa/ Usaha (KPJU) Unggulan Usaha Mikro, Kecil dan Menengah (UMKM) di Provinsi Nusa Tenggara Barat.

Matthew, U., A. Nazemzadeh, O. Gbolahan, and W.J. Etundi, 2004. Social Welfare Effect of Ghana Cocoa Price Stabilization: Time Series Projection and Analysis. International Business and Economics Research Journal, 3 (12): 45-54.

Schmitz, A., H. Furtan, and K. Baylis. 2002. Agricultural Policy, Agribusiness, and RentSeeking Behaviour. University of Toronto Press, Toronto.

Schmitz, Andrew (1984) 'Commodity price stabilization: theory and applications.' Mimeo, Department of Agricultural Economics, University of California, Berkeley.

Van Kooten, G.C. and A. Schmitz 1985. Commodity Price Stabilization: The Price Uncertainty Case. The Canadian Journal of Economics. Vol. 18, No. 2(May, 1985), pp. 426-434. Published by: Wiley-Blackwell. URL:ttp://www.jstor.org/ stable/135146. Accessed: 31/08/2012 19:50.

Zaini, A. (2014). Volatilitas Harga dan Respon Produksi Cabe di Pulau Lombok. Jurnal Agrimansion, 15(1): 31-47.

---------, Suparmin, dan M. Siddik. (2014). Aplikasi Model Oligopolistik Dinamik untuk Mengestimasi Market Power pada Pemasaran Cabe di Pulau Lombok. Laporan Penelitian Fakultas Pertanian Universitas Mataram.

----------- and M Siddik (2019). Welfare analysis on price stabilization: a case study of small chilli in West Nusa Tenggara Province, Indonesia. Paper presented in International Conference at the Rinra Hotel, Makassar on October $21^{\text {st }} 2019$. 